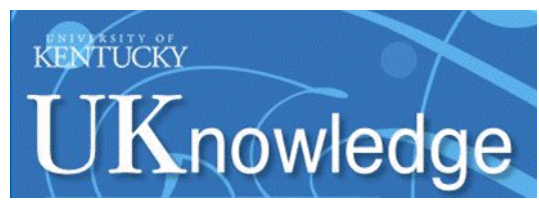

University of Kentucky

UKnowledge

8-25-2014

\title{
Applying Accelerator Mass Spectrometry for Low-Level Detection of Complex Engineered Nanoparticles in Biological Media
}

Binghui Wang

University of Kentucky, binghui.wang@uky.edu

George S. Jackson

Purdue University

Robert A. Yokel

University of Kentucky, ryokel@email.uky.edu

Eric A. Grulke

University of Kentucky, eric.grulke@uky.edu

Right click to open a feedback form in a new tab to let us know how this document benefits you.

Follow this and additional works at: https://uknowledge.uky.edu/ps_facpub

Part of the Chemical Engineering Commons, and the Pharmacy and Pharmaceutical Sciences

Commons 


\title{
Applying Accelerator Mass Spectrometry for Low-Level Detection of Complex Engineered Nanoparticles in Biological Media
}

\author{
Digital Object Identifier (DOI) \\ https://doi.org/10.1016/j.jpba.2014.04.003 \\ Notes/Citation Information \\ Published in Journal of Pharmaceutical and Biomedical Analysis, v. 97. \\ Copyright @ 2014 Elsevier B.V. \\ (c) 2014. This manuscript version is made available under the CC-BY-NC-ND 4.0 license \\ https://creativecommons.org/licenses/by-nc-nd/4.0/.
}

The document available for download is the authors' post-peer-review final draft of the article. 
AMS detection of CENPs

\title{
Applying accelerator mass spectrometry for low-level detection of complex engineered nanoparticles in biological media
}

\author{
Binghui Wang ${ }^{1}$,George S. Jackson ${ }^{2}$, Robert A. Yokel ${ }^{3}$,Eric A. Grulke ${ }^{1, *}$
}

\author{
${ }^{1}$ Departments of Chemical and Materials Engineering, University of Kentucky, Lexington, KY 40506, \\ ${ }^{2}$ Purdue Rare Isotope Measurement Laboratory, Department of Physics, Purdue University, West \\ Lafayette, IN, 47907, ${ }^{3}$ Department of Pharmaceutical Sciences, University of Kentucky, Lexington, KY \\ 40536. * Corresponding author: e-mail: eric.grulke@uky.edu. Tel.: +1 8592676097
}

\section{Abstract}

10 Complex engineered nanoparticles (CENPs), which have different core and surface components, are being

developed for medicinal, pharmaceutical and industrial applications. One of the key challenges for

12 environmental health and safety assessments of CENPs is to identify and quantity their transformations in biological environments. This study reports the effects of in vivo exposure of citrate-coated nanoalumina with different rare isotope labels on each component. This CENP was dosed to the rat and accelerator mass spectrometry (AMS) was used to quantify ${ }^{26} \mathrm{Al},{ }^{14} \mathrm{C}$, and their ratio in the dosing material and tissue samples. For CENPs detected in the liver, the rare isotope ratio, ${ }^{14} \mathrm{C} /{ }^{26} \mathrm{Al}$, was $87 \%$ of the dosing material's ratio. The citrate coating on the nanoalumina in the liver was stable or, if it degraded, its metabolites were incorporated with nearby tissues. However, in brain and bone where little alumina was detected, the rare isotope ratio greatly exceeded that of the dosing material. Therefore, in the animal, citrate dissociated from CENPs and redistributed to brain and bone. Tracking both the core and surface components by AMS presents a new approach for characterizing transformations of CENP components in biological milieu or environments. 
AMS detection of CENPs

\section{$23 \quad$ Highlights}

- The core and coating components of engineered nanoparticles were labeled with rare isotopes.

- These complex nanoparticles were injected into the rat.

- Dose and tissue samples were analyzed for both rare isotopes.

- The rare isotope ratio $\left({ }^{14} \mathrm{C} /{ }^{26} \mathrm{Al}\right)$ demonstrated the relative stability of the two CENP components

\section{Keywords}

complex engineered nanoparticles, nanoalumina, accelerator mass spectrometry, biodistribution

\section{Introduction}

Complex engineered nanoparticles are being developed for a variety of applications such as biomacromolecule receptors [1], biosensors [2], imaging indicators [3] and drug carriers [4]. The core nanoparticles include the metal oxides, such as alumina $\left(\mathrm{Al}_{2} \mathrm{O}_{3}\right)[5]$; ceria $\left(\mathrm{CeO}_{2}\right)[6,7]$; titania $\left(\mathrm{TiO}_{2}\right)[8]$; zirconia $\left(\mathrm{ZrO}_{2}\right)$ [9]; and carbon-based nanomaterials, such as non-functionalized graphene [10, 11], single, and multi-walled carbon nanotubes $[10,12]$. These core materials have extremely low aqueous solubility and therefore persist in biological media with potential to cause delayed toxicity [13-16]. In previous studies, we have found that, in the rat, a single intravenous administration of $30 \mathrm{~nm}$ ceria engineered nanoparticles distributed to specific organs within 24 hours; the ceria levels in these organs did not significantly decrease up to 90 days [17]. The coating materials, such as organic acids, silane coupling agents, proteins, or polymers, can control the dispersion and agglomeration of nanoparticles in fluids; they can also interact with solids and solutes in organisms and in the environment $[11,18,19]$. Citric acid, a tridentate carboxylic acid, has been widely applied on stabilizing metal oxide nanoparticles [20, 21]. The 
AMS detection of CENPs

fate of the citrate coating on these nanoparticles was not known. Therefore, the fate and toxicology of CENPs in biological media depends not only on the physico-chemical attributes of the core nanoparticle (size, size distribution, shape), but also their surface-bound molecular coatings. Material balances need to be performed on both the core and coatings materials in order to properly interpret their transport and transformations over the product life cycle.

The common characterization methods for bio-distribution and bio-persistence of CENPs are highresolution transmission electron microscopy (HR-TEM) [22] and inductively coupled plasma mass spectrometry (ICP-MS) $[23,24]$. The former can give good morphology information but may not provide sufficient chemical analysis. The latter provides good inorganic chemistry information but may not provide sufficient analysis of organic components. Some methods based on radioactive isotopes have been proposed. Perez-Campana et al. [25] utilized ${ }^{13} \mathrm{~N}$-labeled nanoalumina formed by proton beam activation to show bio-distribution in different organs. It verified that nanoalumina accumulated in the liver. As the half-life of ${ }^{13} \mathrm{~N}$ is $9.97 \mathrm{~min}$, it is useful for short time periods only. Rojas et al. [26] used the ${ }^{18} \mathrm{~F}$ isotope to label the amino coating on ceria nanoparticles and showed that ceria accumulated mainly in lungs, spleen, and liver. However, labeling only one component of CENPs is not enough; the components might differentially dissociate, degrade, or transport in biological media.

Therefore, we used one isotope tracer for the core material and another for the coating material. Accelerator mass spectrometry (AMS), the most sensitive form of isotope ratio mass spectrometry, was used to characterize the two tracers. The AMS ion source produced negatively charged cesium ions to sputter the surface atoms of samples. A beam of negative ions, some of which were the radioactive tracer, were produced, and then accelerated to very high speed in a tandem accelerator. At the positive terminal of the tandem accelerator, the negative ions will undergo recharging to positive via a gas or carbon foil electron stripper,. Almost all molecular ions were dissociated in the procedure, since a beam with a positive charge of 4 or greater is typically selected (i.e. at least 5 electrons are removed) and molecular 3 
AMS detection of CENPs

ions dissociate. The ions of the rare isotope were easily selected using electric and magnetic fields and

counted using nuclear detection techniques. One of the abundant stable isotopes is measured on the high energy side of the accelerator (after destruction of interfering molecular isobars) in a faraday cup and this provides the second part of the ratio (oftentimes denoted as rare/stable) $[27,28]$. Therefore, this analysis tool can separate rare isotopes with high selectivity and sensitivity, detecting such species at levels $10^{3}$ to $10^{9}$ times lower than other methods $[29,30]$. It has been applied in pharmaceutical and toxicological studies to investigate metabolism of drugs [31], covalent bonding of metabolite to RNA/ protein [32] and 76 imaging of radioactive label $[33,34]$.

[This is not a complete sentence]Using AMS techniques to find and quantity low levels of complex nanoparticle components in biological systems where transporting or transformations might take place. Moreover, it should be possible to identify changes in the molar ratio (coating:core) after biological exposures of CENPs. Dual tracer technology should provide an understanding of the biodistribution and transformation of CENPs in various milieus. In this study, nanoalumina was used as the core material. It has very low solubility in aqueous systems and is relatively common in the environment; it has potential to enter biological tissue and persist there. The nanoalumina was synthesized using a hydrothermal system. ${ }^{26} \mathrm{Al}$ was introduced in the synthesis as the core material tracer. Hydroxyl groups on the nanoalumina surface can react with ${ }^{14} \mathrm{C}$-labeled citric acid, used as a coating material. The citric acid was either covalently bound to the nanoparticle or self-crosslinked on the surface. The CENP, ${ }^{26} \mathrm{Al}-\mathrm{labeled}$ nanoalumina core with ${ }^{14} \mathrm{C}$-labeled coating, was infused into rats. The dosing material and selected tissues were analyzed by AMS in Purdue Rare Isotope Measurement Laboratory (PRIME lab) to quantify ${ }^{26} \mathrm{Al}$ and ${ }^{14} \mathrm{C}$. 
AMS detection of CENPs

91

92

93

94

95

96

97

98

99

100

101

102

103

104

105

106

107

108

109

110

111

\section{Experiments}

\subsection{Synthesis of neat nanoalumina}

The synthesis route was modified from Chuah's work [35]. $0.001 \mathrm{~mol}$ of anhydrous aluminum chloride $\left(\mathrm{AlCl}_{3}, \mathrm{Acros}\right)$ was dissolved in $10 \mathrm{~mL} 1 \mathrm{M} \mathrm{HCl}$ solution to form $0.1 \mathrm{~mol} / \mathrm{L} \mathrm{AlCl}_{3}$ solution. Anhydrous $\mathrm{AlCl}_{3}$ has a very high tendency to hydrolyze so it was dissolved in an acidic solution at a $\mathrm{pH}$ of about 2.5 to avoid precipitation. $1 \mathrm{~mL}{ }^{26} \mathrm{Al}-\mathrm{HCl}$ solution $(16.5 \mathrm{nCi} / \mathrm{mL}$, provided by the PRIME Lab) was diluted 10 -fold. $600 \mu \mathrm{L}$ of the diluted solution $\left(1 \mathrm{nCi}^{26} \mathrm{Al}\right.$ ) was added to the $\mathrm{AlCl}_{3}$ solution. $0.5 \mathrm{M} \mathrm{NaOH}$ solution was added dropwise into the aluminum chloride solution with stirring until the $\mathrm{pH}$ was 9.5 . $\mathrm{AlO}(\mathrm{OH})$ and $\mathrm{Al}(\mathrm{OH})_{3}$ are formed in the process (scheme 1).

$$
\mathrm{AlCl}_{3}+3 \mathrm{NaOH} \rightarrow \mathrm{AlO}(\mathrm{OH})+3 \mathrm{NaCl}+\mathrm{H}_{2} \mathrm{O}
$$
$\mathrm{AlCl}_{3}+3 \mathrm{NaOH} \rightarrow \mathrm{Al}(\mathrm{OH})_{3}+3 \mathrm{NaCl}$
Scheme 1

The obtained white opaque mixtures were transferred to PTFE containers. The containers were inserted into a metal container (Parr Instrument Company, Models 4746). They were put in a furnace at $190{ }^{\circ} \mathrm{C}$ for $24 \mathrm{~h}$, and then cooled to room temperature. The products were washed with distilled water three times and ultracentrifuged to remove the remaining $\mathrm{Al}^{3+}$ ion. The solid samples were dried at $90^{\circ} \mathrm{C}$ for $2 \mathrm{~h}$ to remove the adsorbed water and then heated to $600^{\circ} \mathrm{C}$ for $1 / 2 \mathrm{~h}$. The $\mathrm{AlO}(\mathrm{OH})$ and $\mathrm{Al}(\mathrm{OH})_{3}$ nanoparticles decomposed to form $\gamma$-alumina nanoparticles via calcination (scheme 2) [36].

$$
\begin{aligned}
& 2 \mathrm{AlO}(\mathrm{OH}) \rightarrow \mathrm{Al}_{2} \mathrm{O}_{3}+\mathrm{H}_{2} \mathrm{O} \\
& 2 \mathrm{Al}(\mathrm{OH})_{3} \rightarrow \mathrm{Al}_{2} \mathrm{O}_{3}+3 \mathrm{H}_{2} \mathrm{O} \quad \text { Scheme } 2
\end{aligned}
$$

The final samples were named "neat nanoalumina". The weight was $40 \mathrm{mg}, 80 \%$ of the expected product mass. The expected radioactivity was ${ }^{26} \mathrm{Al} 0.02 \mathrm{nCi} / \mathrm{mg}$. 
AMS detection of CENPs

\section{$112 \quad 2.2$ Formation of citrate-coated nanoalumina}

113 For coating nanoalumina with citric acid, $400 \mathrm{mg}$ citric acid (MW=192, citric acid: alumina=10:1 w/w)

114 was dissolved in $4 \mathrm{~mL}$ water. $50 \mu \mathrm{L}$ citric acid with ${ }^{14} \mathrm{C}(0.05 \mathrm{mCi} / \mathrm{mL}$, Amersham Bioscience UK limited,

115 CFA263) was diluted into $5 \mathrm{~mL}$, to $0.5 \mu \mathrm{Ci} / \mathrm{mL}$. $500 \mu \mathrm{L}$ of this diluted solution $\left(250 \mathrm{nCi}{ }^{14} \mathrm{C}\right)$ was added

116 to the citric acid solution. Thermo-gravimetrical analysis showed that the adsorbed citric acid was $0.32 \%$

117 of that added. The adsorbed ${ }^{14} \mathrm{C}$ citric acid should have $0.8 \mathrm{nCi}$ if the adsorbed/total ratio didn't change.

$11840 \mathrm{mg}$ of neat nanoalumina was added to the citric acid solution, then the mixture was stirred for $24 \mathrm{~h}$. The

119 sample was washed by distilled water, ultracentrifuged and recovered three times to remove the free citric

120 acid, and then was dried at $90^{\circ} \mathrm{C}$ for $2 \mathrm{~h}$. The dried sample was named "citrate-coated nanoalumina" with

121 an expected radioactivity of $0.02 \mathrm{nCi} / \mathrm{mg}$.

\section{$122 \quad 2.3$ Characterization of nanoalumina}

123 The shape and morphology of neat nanoalumina were observed by scanning electron microscopy (SEM,

124 Hitachi 4300, University of Kentucky). Quantitation of hydroxyl and citrate groups on the surfaces of neat

125 and citrated-coated nanoalumina was done via thermo gravimetric analysis (TGA) (Perkin Elmer, TGA-7

126 Thermo gravimetric Analyzer). In a nitrogen environment, the neat and citrate-coated nanoalumina were

127 heated from room temperature to $110^{\circ} \mathrm{C}$, kept at $110^{\circ} \mathrm{C}$ for $1 / 2 \mathrm{~h}$ to remove physically-adsorbed water,

128 then heated to $750{ }^{\circ} \mathrm{C}$ at a rate of $10^{\circ} \mathrm{C} / \mathrm{min}$. Within the higher temperature range, hydroxyl groups at the

129 metal oxide surface will dehydrate to form water and the citrate coating will decompose to form carbon

130 dioxide and ethylene [37]. To analyze the ability of citrate coating to create astable dispersion, some neat

131 and citrate-coated nanoaluminas were dispersed in water with ultrasonication. The particle distribution in

132 the dispersion was measured by dynamic light scattering (90 Plus, particle size analyzer, Brookhaven

133 Instrument Corporation).

\section{$134 \quad 2.4$ Animal infusions}


AMS detection of CENPs

$13520 \mathrm{mg}$ of the citrate-coated nanoalumina was put into $1 \mathrm{ml}$ water then ultrasonicated; the dispersion was

136 expected to have $0.4 \mathrm{nCi}^{26} \mathrm{Al}$ and $0.4 \mathrm{nCi}{ }^{14} \mathrm{C} / \mathrm{ml}$. One rat was intravenously infused, via a cannula

137 inserted into a femoral vein that terminated in the vena cava, with $0.4 \mathrm{ml}$ of this dispersion (anticipated

138 dose $0.16 \mathrm{nCi}^{26} \mathrm{Al}$ and $\left.0.16 \mathrm{nCi}{ }^{14} \mathrm{C}\right)$. The dosed animal was terminated 30 days later and tissues,

139 including liver, brain, and bone, were collected. The similar tissues from one un-dosed rat were collected

140 as the control samples.

\section{$141 \quad 2.5$ Sample preparation and AMS quantification of ${ }^{26} \mathrm{Al}$}

142 The pathways to analyze ${ }^{26} \mathrm{Al}$ and ${ }^{14} \mathrm{C}$ are described in the following paragraphs and summarized in

143 Scheme-3 and Scheme-4.

144 To quantify ${ }^{26} \mathrm{Al}$ in the dosing material, it was diluted 100 -fold to form a $0.2 \mathrm{mg} / \mathrm{mL}$ dispersion. $400 \mu \mathrm{L}$ of

145 the commercial analytical standard $\mathrm{Al}$ in $\mathrm{HCl}$ solution (Aluminum Standard for ICP, 10,000 mg/L in 5\%

146 nitric acid, 41377 Fluka) was added to two $10 \mu \mathrm{L}$ aliquots of the diluted dosing material ( $\mathrm{Al}_{2} \mathrm{O}_{3}-1$ and

$\left.147 \mathrm{Al}_{2} \mathrm{O}_{3}-2\right)$. This enabled determination of the ${ }^{26} \mathrm{Al} /{ }^{27} \mathrm{Al}$ ratio by introducing a known amount of ${ }^{27} \mathrm{Al}(4 \mathrm{mg})$

148 that greatly exceeded the ${ }^{27} \mathrm{Al}$ in the sample. This was done to provide enough material for the AMS

149 measurement. The two samples were then dried and ashed at $1000^{\circ} \mathrm{C}$.

150 To quantify ${ }^{26} \mathrm{Al}$ in tissue samples, each sample (from the dosed and control animals) was transferred to a

151 scrupulously cleaned, pre-weighed, 7-ml Teflon screw-cap container and re-weighed to obtain sample

152 weight. Four $\mathrm{mg}$ of ${ }^{27} \mathrm{Al}$ from the standard $\mathrm{HCl}$ solution was added to each sample. The mixture was dried

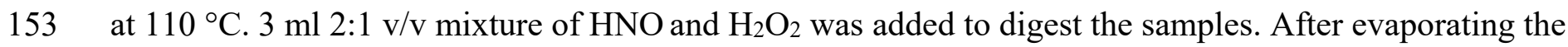

154 liquid using a heatable, semi-closed system [38], the samples (except brain samples) were ashed at

$1551000{ }^{\circ} \mathrm{C}$. For brain samples, direct ashing will result in some glasslike material believed to be aluminum

156 oxyphosphate. A procedure that separates $\mathrm{Al}$ from phosphate was used [39]. A diluted mixture of $\mathrm{HNO}_{3}$

157 and $\mathrm{H}_{2} \mathrm{O}_{2}$ was used to solubilize the residue after evaporating the liquid. Two grams of cation exchange 
AMS detection of CENPs

resin containing a sulfonic acid functional group (AG 50-X8, 100-200 mesh; Bio-Rad) was used to complex the $\mathrm{Al}^{3+}$. After washing three times with $5 \mathrm{~mL} 0.2 \% \mathrm{HNO}_{3}, 5 \mathrm{~mL}$ of $1 \mathrm{M}$ hydrofluoric acid (HF) was used to elute $\mathrm{Al}$ from the resin. The solution was dried by evaporation then ashed at $1000{ }^{\circ} \mathrm{C}$. The dosing material and tissue samples were sent to the PRIME lab for ${ }^{26} \mathrm{Al}$ quantification by AMS. Upon receipt at the PRIME Lab, the samples were mixed with $\mathrm{Ag}$ in an approximately $2: 1, \mathrm{Ag}: \mathrm{Al}_{2} \mathrm{O}_{3}$ weight ratio. After mixing, the sample was inserted into a cavity in a sample holder (cathode) that was 0.040 " in diameter and 0.080 " deep. The silver greatly increases the current out of the cesium sputter source and increases efficiency of the measurement. The cathode was inserted into the PRIME Lab ion source. A

typical sample will produce a current of $500 \mathrm{nA}$ in the source which translates to a count rate of

approximately 25 counts per minute for a sample with a ${ }^{26} \mathrm{Al} /{ }^{27} \mathrm{Al}$ ratio of $10^{-12}$. Standards of known value were measured before and after the assay of the unknowns and were used to normalize the ratios. Samples were typically measured until they were used up or a precision of $3 \%$ was achieved.

\subsection{Sample preparation and AMS quantification of ${ }^{14} \mathrm{C}$}

To quantify ${ }^{14} \mathrm{C}$ in the dosing material, it was diluted 10 -fold to form a $2 \mathrm{mg} / \mathrm{mL}$ dispersion. Three $10 \mu \mathrm{L}$ aliquots of the diluted dispersion were collected (CA-1, CA-2 and CA-3). The CA 1-3 samples were sent to the PRIME lab. For the dose material dilutions, tributyrin was added directly to the sample. Tributyrin has no vapor pressure to speak of and is carbon rich. The ${ }^{14} \mathrm{C}:{ }^{12} \mathrm{C}$ ratio of the tributyrin is almost exactly 5 $\mathrm{x} 10^{-14}$. The mixture was placed in a small quartz tube that was nestled in a Pyrex tube with a glass microfiber filter in the top. The Pyrex tube was then placed in a centrifuge tube with another glass microfiber filter in the top. The lid of the centrifuge tube had a few small holes drilled for water vapor removal. This apparatus was then placed in a centrifuge and spun under vacuum for $24 \mathrm{~h}$ to remove the water. The sample was then placed in a combustion tube with appropriate reactants, pumped to less than 
AMS detection of CENPs

18115 microns as recorded by a gauge on the vacuum line. The tube was sealed with a torch, and placed in an

182 oven to be combusted. The $\mathrm{CO}_{2}$ was then transferred to another tube and graphitized using the method

183 developed by Ognibene et.al [40].

184 The tributyrin method was good for the dosing material, since it had a very low content of carbon material. There was not enough material for an accurate AMS measurement without addition of a carrier.

186 However, the tissue samples provide sufficient carbon content to permit direct measurements of the

$187{ }^{14} \mathrm{C} /{ }^{12} \mathrm{C}$ ratio without addition of a carrier. The tissue sample was located in a combustion tube with

188 appropriate reactants, the tube sealed with a torch, and the contents combusted, as above. $\mathrm{The}_{2} \mathrm{CO}_{2} \mathrm{was}$

189 then transferred to another tube and graphitized as above. After graphitization, the sample was transferred

190 into an aluminum sample holder (cathode) and pressed into a 0.040 " diameter hole that was 0.040 " deep.

191 The sample holder was then placed into the PRIME Lab ion source (reference below) which typically

192 generates ${ }^{13} \mathrm{C}$-currents of $500-750 \mathrm{nA}$ with the corresponding ${ }^{14} \mathrm{C}^{4+}$ ion detection rates of about $200 \mathrm{~Hz}$ for

193 a sample ${ }^{14} \mathrm{C}$-enrichment of about $2 \times 10^{-12}$ of total carbon. The ${ }^{14} \mathrm{C} /{ }^{12} \mathrm{C}$ ratios were analyzed with no $\delta^{13} \mathrm{C}$

194 correction. Standards of known ratio are constantly measured to normalize the values of the unknown.

195 Samples were typically measured until they were used up or a precision of 1\% was achieved.

197 Ion source reference (can be used for both the aluminum and carbon AMS part): G.S. Jackson, D. Elmore, 198 M. Caffee, K.A. Mueller, B. De Bonte, P. Muzikar, B. Alexander, Nuclear Instruments and Methods in 199 Physics Research Section B: Beam Interactions with Materials and Atoms 223-224 (2004) 155. 
AMS detection of CENPs

203 Figure 1 shows the morphology of neat nanoalumina. The top surfaces of most nanoalumina were square.

204 It is not very easy to determine if they were cubic or square disks. The typical particle size was 50 to 80

$205 \mathrm{~nm}$. However, some smaller $(30 \mathrm{~nm})$ and larger particles $(100 \mathrm{~nm})$ existed, which may come from

206 sintering and Ostwald ripening in the hydrothermal and calcination processes. Figure 2 shows the volume-

207 averaged particle size distribution of neat and citrate-coated nanoalumina in their dispersion. The

208 dispersion of neat nanoalumina showed three peaks: one centered at $95 \mathrm{~nm}(65 \mathrm{~nm}<\mathrm{D}<180 \mathrm{~nm})$; one

209 over the range, $230 \mathrm{~nm}$ to $500 \mathrm{~nm}$; and one over the range, $1 \mu \mathrm{m}$ to $2 \mu \mathrm{m}$. The peak centered at $95 \mathrm{~nm}$ was

210 consistent with the size observed in SEM. The larger peaks likely represent agglomerates. The dispersion

211 of citrate-coated nanoalumina showed only two peaks: one over the range of 65 to $105 \mathrm{~nm}$ with a peak at

$21283 \mathrm{~nm}$ and a second over the range, 230 to $360 \mathrm{~nm}$. No larger agglomerates were observed. The results

213 shows the citrate coating helped stabilize the dispersion of nanoalumina.

\section{$214 \quad 3.2$ Thermogravimetric analysis of nanoalumina}

215 Figure 3 shows the TGA curves of neat and citrate-coated nanoalumina. The weight of the neat

216 nanoalumina decreased $0.68 \%$ due to the loss of surface hydroxyls. Based on a method to estimate surface

217 density of functional groups [24], the sample had a surface density of 17 hydroxyl groups $/ \mathrm{nm}^{2}$, assuming

218 an average particle was a $60 \mathrm{~nm}$ cube. For the citrate-coated nanoalumina, the weight loss was $3.85 \%$. The

$2193.2 \%$ difference was attributed to decomposition of the citrate coating. The estimated surface density of

220 citric acid is 3.3[Doesn't this need some unit?] $/ \mathrm{nm}^{2}$. Using a molecular diameter of citric acid of $0.57 \mathrm{~nm}$

221 [41], the coverage of citrate-coating was estimated to be $77 \%$ [42].

\section{$222 \quad 3.3{ }^{26} \mathrm{Al}$ in dosing material}

223 Table 1 shows the ratio of ${ }^{26} \mathrm{Al} /{ }^{27} \mathrm{Al}$ obtained by AMS and the calculated fraction of ${ }^{26} \mathrm{Al}$ in samples. The $224{ }^{26} \mathrm{Al} /{ }^{27} \mathrm{Al}$ ratio in dosing material sample $\mathrm{Al}_{2} \mathrm{O}_{3}-1$ was $1.41 \times 10^{-9}$. The number of ${ }^{26} \mathrm{Al}^{\text {in } \mathrm{Al}_{2} \mathrm{O}_{3}-1 \text { was }}$ 
AMS detection of CENPs

average number of ${ }^{26} \mathrm{Al}$ atoms in $\mathrm{Al}_{2} \mathrm{O}_{3}-1$ and $\mathrm{Al}_{2} \mathrm{O}_{3}-2$ was $1.16 \times 10^{11}$. Both of them were $10 \mu \mathrm{L}$ aliquots of 100-fold diluted dosing material. So the dosing material had an average number concentration of $1.16 \times 10^{15}{ }^{26} \mathrm{Al} / \mathrm{ml}$. The treated rat received $0.4 \mathrm{ml}$ of the dosing material, corresponding to $4.65 \times 10^{1426} \mathrm{Al}$ atoms or $0.383 \mathrm{nCi}$. It was 2.4 times the planned dose.

\section{$3.4{ }^{26} \mathrm{Al}$ in tissue samples}

The ${ }^{26} \mathrm{Al} /{ }^{27} \mathrm{Al}$ ratio in liver-1 sample $(38.7 \mathrm{mg})$ was $2.41 \times 10^{-9}$. The liver-1 sample contained $2.15 \times 10^{11}$ ${ }^{26} \mathrm{Al}$ atoms. The liver weight from dosed and control rats was around 16.3 grams so the total liver would contain $9.06 \times 10^{1326} \mathrm{Al}$ atoms or $7.47 \times 10^{-2} \mathrm{nCi}$, corresponding to $19.5 \%$ of the dose. The ${ }^{26} \mathrm{Al} /{ }^{27} \mathrm{Al}$ ratio in liver-2 $(35.9 \mathrm{mg})$ was $7.61 \times 10^{-13}$. The liver-2 sample contained $6.78 \times 10^{7}{ }^{26} \mathrm{Al}$ atoms so the total liver of control rat would contain $3.08 \times 10^{1026} \mathrm{Al}$ atoms or $2.54 \times 10^{-5} \mathrm{nCi}$, more than 3 orders of magnitude less than the liver from the dosed rat. The weight of liver was about 3.2\% of the rat's weight and contained $19.5 \%$ of dose, showing accumulation of the nanoalumina in the liver.

The ${ }^{26} \mathrm{Al} /{ }^{27} \mathrm{Al}$ ratio in the brain-1 sample was $5.99 \times 10^{-11}$. Brain-1 sample $(757.1 \mathrm{mg})$ contained $5.35 \times 10^{9}$

${ }^{26} \mathrm{Al}$ atoms. The average weight of a rat's brain is 1.86 gram so the total brain would contain 1.31 $\times 10^{1026} \mathrm{Al}$ atoms or $1.08 \times 10^{-5} \mathrm{nCi}$, about $0.003 \%$ of the dosing material. The ${ }^{26} \mathrm{Al} /{ }^{27} \mathrm{Al}$ ratio in brain- 2 was $5.01 \times 10^{-11}$. Brain-2 sample $(738 \mathrm{mg})$ contained $4.47 \times 10^{9}{ }^{26} \mathrm{Al}$ atoms so the total brain from control rat contained $1.13 \times 10^{10} \mathrm{nCi}^{26} \mathrm{Al}$ atoms or $9.27 \times 10^{-6} \mathrm{nCi}$.

The ${ }^{26} \mathrm{Al} /{ }^{27} \mathrm{Al}$ background for samples without ${ }^{26} \mathrm{Al}$ was around $10^{-14}$ in the AMS measurements. So the high ${ }^{26} \mathrm{Al} /{ }^{27} \mathrm{Al}$ ratio in the control rat suggests that some low-level contamination happened during infusion or surgery. We can't compare the actual difference between the ${ }^{26} \mathrm{Al}$ in (brains?) from dosed and control rats. However, the $0.003 \%$ of dosing material can be considered as the upper limit of ${ }^{26} \mathrm{Al}$ in the brain from dosed rats. It indicates only a very small amount (if any) of the ${ }^{26} \mathrm{Al}$ got incorporated into the brain since the nanoalumina did not cross the blood-brain barrier to enter brain parenchyma. 
AMS detection of CENPs

$249 \mathrm{The}{ }^{26} \mathrm{Al} /{ }^{27} \mathrm{Al}$ ratio in bone-1 sample was $4.62 \times 10^{-12}$. The bone- 1 tissue $(52 \mathrm{mg})$ contained $4.12 \times 10^{8}{ }^{26} \mathrm{Al}$

250 atoms. The total rat skeletal weight is about of $5 \%$ of body weight ( 25 gram). So the total skeletal system

251 would contain $1.98 \times 10^{11}{ }^{26} \mathrm{Al}$ atoms or $1.63 \times 10^{-4} \mathrm{nCi}, 0.043 \%$ of the dose. The bone-2 $(50.8 \mathrm{mg})$

252 contained $7.52 \times 10^{8}{ }^{26} \mathrm{Al}$ atoms, translating to a total rat skeletal content of $3.05 \times 10^{-4} \mathrm{nCi}$. The control rat

253 bone had higher radioactivity in the bone than the dosed animal. The unexpected result may be from the

254 same low level contamination that affected the brain. The $0.043 \%$ of dosing material was used as the

255 upper limit and indicates only small amount (if any) of the ${ }^{26} \mathrm{Al}$ got incorporated into the brain. In the

256 typical mammal, $60 \%$ of the body burden of $\mathrm{Al}$ is in the skeletal system and only $3 \%$ in the liver [43]. The

257 high concentration of ${ }^{26} \mathrm{Al}$ in liver and low concentration in bone suggests that the ${ }^{26} \mathrm{Al}$ from the

258 nanoalumina is difficult to dissolve and redistribute into bone.

\section{$3 .{ }^{14} \mathrm{C}$ in dosing material}

260 Table 2 shows the ratio of ${ }^{14} \mathrm{C} /{ }^{12} \mathrm{C}$ obtained by AMS and the calculated sample activity. The ${ }^{14} \mathrm{C} /{ }^{12} \mathrm{C}$ in 261 CA-1, CA-2, and CA-3 samples was 10353, 9342, and 8359, giving an average number of $1.1 \times 10^{914} \mathrm{C}$ 262 atoms in the three aliquots. They were $10 \mu \mathrm{L}$ aliquots of 10 -fold diluted dosing material so the dosing 263 material had number concentration of $1.1 \times 10^{12}{ }^{14} \mathrm{C}$ atoms $/ \mathrm{mL}$. The rat got $0.4 \mathrm{~mL}$ of the dosing material, 264 corresponding to $4.40 \times 10^{11}{ }^{14} \mathrm{C}$ atoms or $4.56 \times 10^{-2} \mathrm{nCi}$. It was $28.5 \%$ of the planned dose.

\section{$265 \quad 3.6{ }^{14} \mathrm{C}$ in tissue samples}

266 Because ${ }^{14} \mathrm{C}$ is ubiquitous in air, water and food, it inevitably enters the animal to become stored and form

267 the ${ }^{14} \mathrm{C}$ background. The typical ratio ${ }^{14} \mathrm{C} /{ }^{12} \mathrm{C}$ of mammal's tissue sample via previous AMS

268 measurements is around 1250. It is very close to a value reported in literature [44]. However, the precise

269 ratio in each organ does vary, so we used the ratios in the control rat as our background.

270 After subtracting the average ${ }^{14} \mathrm{C} /{ }^{12} \mathrm{C}$ ratio background (1437.5) from Liver-2 and Liver-3 samples, the 271 actual ${ }^{14} \mathrm{C} /{ }^{12} \mathrm{C}$ ratio in liver-1 sample was 607.5 . The typical carbon percent in liver is $15 \mathrm{wt} \%$. There are 
AMS detection of CENPs

272

$1.23 \times 10^{23}{ }^{12} \mathrm{C}$ atoms in total liver (16.3 grams). The calculated ${ }^{14} \mathrm{C}$ in the total liver of the dosed rat was $7.45 \times 10^{10}$ or $7.72 \times 10^{-3} \mathrm{nCi}, 16.9 \%$ of the dose. The ${ }^{14} \mathrm{C}$ of the coating material concentrated in the liver of the dosed rat, but the differences between the dosed rat and the controls was not as large as those for the core material, ${ }^{26} \mathrm{Al}$.

The ${ }^{14} \mathrm{C} /{ }^{12} \mathrm{C}$ ratio (1261) from Brain-2 of the control rat was used as the background. After subtracting background, the ${ }^{14} \mathrm{C} /{ }^{12} \mathrm{C}$ in brain-1 sample is 22 . The difference is larger than one standard deviation of the measured value so there was some higher amount of ${ }^{14} \mathrm{C}$ in brain of the dosed rat than the control rat in a statistically significant sense. The typical carbon percent in brain is $15 \mathrm{wt} \%$. There are $1.40 \times 10^{22}{ }^{12} \mathrm{C}$ atoms in the total brain (1.86 grams). The total brain would contain $3.08 \times 10^{8}{ }^{14} \mathrm{C}$ atoms or $3.19 \times 10^{-5} \mathrm{nCi}$, $0.07 \%$ of the dosage. For the Brain-3 sample, the ${ }^{14} \mathrm{C} /{ }^{12} \mathrm{C}$ ratio is much higher than brain-2 sample, even brain-1. The contamination may have come from a previous sample with high ratio of ${ }^{14} \mathrm{C} /{ }^{12} \mathrm{C}$ that was dried in the vacuum centrifuge. This seemed highly likely since a check of the records at the PRIME Lab showed that the one sample was dried with a batch of samples that had ${ }^{14} \mathrm{C} /{ }^{12} \mathrm{C}$ ratios 100 times higher. Thus, it was considered safe to discard this result.

After subtracting the average ${ }^{14} \mathrm{C} /{ }^{12} \mathrm{C}$ ratio background (1412.5) from Bone-2 and Bone-3 samples, the actual ratio of ${ }^{14} \mathrm{C} /{ }^{12} \mathrm{C}$ in bone-1 sample was 76.5 . The typical carbon percent in bone was around $12 \%$ [45]. There are $1.51 \times 10^{23}{ }^{12} \mathrm{C}$ atoms in total bone (25 grams). The total bone would contain $1.16 \times 10^{10}{ }^{14} \mathrm{C}$ atoms or $1.20 \times 10^{-3} \mathrm{nCi}, 2.63 \%$ of the dosage. The bone from the dosed rat had higher ${ }^{14} \mathrm{C}$ than that from the control rat.

\subsection{The ratio of coating/core and material balance}

The ratio between ${ }^{14} \mathrm{C} /{ }^{26} \mathrm{Al}$ in different organs and the mass distribution are shown in Table 3 . In the dosing material, the average numbers of ${ }^{26} \mathrm{Al}$ and ${ }^{14} \mathrm{C}$ atoms were $4.65 \times 10^{14}$ and $4.40 \times 10^{11}$ respectively. 
AMS detection of CENPs

294 The ${ }^{14} \mathrm{C} /{ }^{26} \mathrm{Al}$ was $9.46 \times 10^{-4}$. The total recovered ${ }^{26} \mathrm{Al}$ and ${ }^{14} \mathrm{C}$ from liver, brain and bone are $19.5 \%$ and $19.6 \%$ of the dosing material respectively.

296

The numbers of isotope atoms in the dosed liver were: ${ }^{26} \mathrm{Al}=9.06 \times 10^{13}$ and ${ }^{14} \mathrm{C}=7.45 \times 10^{10}$. The ${ }^{14} \mathrm{C} /{ }^{26} \mathrm{Al}$ in liver of the dosed rat was $8.22 \times 10^{-4}$, around $87 \%$ of the ratio in the dosing material. The citrated coating entering the liver (19.5\% of dosage) partially dissociated from the nanoalumina, and would have been available to redistribute into organs such as the brain and bone.

The average numbers of isotope atoms in brain were: ${ }^{26} \mathrm{Al}<1.31 \times 10^{10}$ and ${ }^{14} \mathrm{C}=3.08 \times 10^{8}$, for a ${ }^{14} \mathrm{C} /{ }^{26} \mathrm{Al}$ ratio $>2.35 \times 10^{-2}$. The average numbers of isotope atoms in bone were: ${ }^{26} \mathrm{Al}<1.98 \times 10^{11}$ and ${ }^{14} \mathrm{C}=$ $1.16 \times 10^{10}$, for a ${ }^{14} \mathrm{C} /{ }^{26} \mathrm{Al}$ calculated ratio $>5.81 \times 10^{-2}$. Both of these ratios are much higher than that of the dosing material. The reason is that ${ }^{14} \mathrm{C}$ preferentially accumulated in brain $(0.07 \%)$ and bone $(2.63 \%)$ compared to the levels of ${ }^{26} \mathrm{Al}$ in these two organs $(0.003 \%$ and $0.043 \%$, respectively). This finding suggests that some of the citrate coating dissociated from the nanoalumina's surface and then redistributed to organs such as the brain and bone.

\section{Conclusions}

The core and surface coatings of a complex engineered nanoparticle have been tracked during biological exposure to the rat using rare isotope labels detected by AMS. The alumina core was tracked using ${ }^{26} \mathrm{Al}$ and the citrate coating was tracked using ${ }^{14} \mathrm{C}$. Comparison of the rare isotope levels and their ratios, ${ }^{14} \mathrm{C}:{ }^{26} \mathrm{Al}$, in different organs demonstrated the relative stability of the two CENP components. The amount of ${ }^{26} \mathrm{Al}$ in the liver of the dosed rat was higher than that of control rats. The amounts of ${ }^{26} \mathrm{Al}$ in brain and bone of the dosed rat were similar to those of the control rat. It suggests the nanoalumina accumulated, and persisted in the liver 30 days after infusion. The amounts of ${ }^{14} \mathrm{C}$ in the liver, bone, and brain of the dosed rat were also higher than those of the control rats. However, the ${ }^{14} \mathrm{C} /{ }^{26} \mathrm{Al}$ ratios differed between 14 
AMS detection of CENPs

317 liver, brain, and bone. Slightly less coating material went to the liver compared to the core material and its

318 levels were significantly higher in brain and bone compared to the core material. Some of the citrate

319 coating dissociated from the nanoparticle surfaces and redistributed to organs such as the brain and bone.

320 AMS methodology provides a new opportunity to characterize the biodistribution of complex engineering

321 nanomaterials.

\section{Acknowledgement}

This work was supported by National Science Foundation to "EAGER: Low-level detection of complex nanomaterials in biological media" [Award Abstract \#1249123]. Although the research described in this article has been funded wholly or in part by the National Science Foundation, it has not been subjected to

National Science Foundation and no official endorsement should be inferred.

\section{References}

[1] A. Verma, V.M. Rotello, Chem. Commun., (2005) 303-312.

[2] M. De, S. Rana, H. Akpinar, O.R. Miranda, R.R. Arvizo, U.H.F. Bunz, V.M. Rotello, Nat. Chem, 1 (2009) 461-465.

[3] A.M. Smith, H.W. Duan, A.M. Mohs, S.M. Nie, Adv. Drug Delivery Rev, 60 (2008) 1226-1240.

[4] M.E. Davis, Z. Chen, D.M. Shin, Nat. Rev. Drug Discovery, 7 (2008) 771-782.

[5] M. Pailleux, D. Boudard, J. Pourchez, V. Forest, P. Grosseau, M. Cottier, Toxicology In Vitro, 27 (2013) 10491056.

[6] R.A. Yokel, M.T. Tseng, M. Dan, J.M. Unrine, U.M. Graham, P. Wu, E.A. Grulke, Nanomedicine (New York, NY, United States), 9 (2013) 398-407.

339 [7] X. Huang, B. Wang, E.A. Grulke, M.J. Beck, Journal of Chemical Physics, 140 (2014) 074703/074701-

$340 \quad 074703 / 074709$.

341 [8] K. Hund-Rinke, T. Klawonn, in, Fraunhofer Institute for Molecular Biology and Applied Ecology IME, 342 Schmallenberg, Germany., 2013, pp. F/1-F/3, i-xxv, 1-431. Science and Engineering, 38 (2012) 012050/012051-012050/012054. 
AMS detection of CENPs

350

351

352

353

354

355

356

357

358

359

360

361

362

363

364

365

366

367

368

369

370

371

372

373

374

375

376

377

378

379

380

381

382

383

384

385

386

387

388

389

390

391

392

393

394

395

396

397

[15] J. Ai, E. Biazar, M. Jafarpour, M. Montazeri, A. Majdi, S. Aminifard, M. Zafari, H.R. Akbari, H.G. Rad, International Journal of Nanomedicine, 6 (2011) 1117-1127.

[16] Z. Li, Y. Geng, X. Zhang, W. Qi, Q. Fan, Y. Li, Z. Jiao, J. Wang, Y. Tang, X. Duan, W. Wu, J. Nanopart. Res., 13 (2011) 2939-2947.

[17] R.A. Yokel, T.C. Au, R. MacPhail, S.S. Hardas, D.A. Butterfield, R. Sultana, M. Goodman, M.T. Tseng, M. Dan, H. Haghnazar, J.M. Unrine, U.M. Graham, P. Wu, E.A. Grulke, Toxicological Sciences, 127 (2012) 256-268.

[18] I. Lynch, K.A. Dawson, Nano Today, 3 (2008) 40-47.

[19] T. Cedervall, I. Lynch, S. Lindman, T. Berggard, E. Thulin, H. Nilsson, K.A. Dawson, S. Linse, Proceedings of the National Academy of Sciences of the United States of America, 104 (2007) 2050-2055.

[20] R. Yokel, Grulke, E., MacPhail, R. Metal-based nanoparticle interactions with the nervous system: the challenge of brain entry and the risk of retention in the organism, WIREs Nanomed Nanobiotechnol, 5 (2013) 346373.

[21] T.M. Dan M, Wu P, Unrine JM, Grulke EA, Yokel RA., Int J Nanomedicine, 7 (2012) 4023-4036.

[22] A.B. Al Faraj, Amine; Cieslar, Katarzyna; Lacroix, Ghislaine; Canet-Soulas, Emmanuelle; Cremillieux, Yannick, nanotechnology, 21 (2010) 175103/175101-175103/175109.

[23] Y.Y. Tsutsumi, Yasuo, Nature Nanotechnology, 6 (2011).

[24] V.W. Kanniah, Binghui; Yang, Ying; Grulke, Eric A, Journal of Applied Polymer Science, 125 (2012) 165-174.

[25] C. Perez-Campana, V. Gomez-Vallejo, M. Puigivila, A. Martin, T. Calvo-Fernandez, S.E. Moya, R. Ziolo, T. F.Reese, J. Llop, ACS NANO, 7 (2013) 3498-3505.

[26] S. Rojas, J.D. Gispert, S. Abad, M. Buaki-Sogo, V.M. Victor, H. Garcia, J.R. Herance, Mol. Pharmaceutics, 9 (2012) 3543-3550.

[27] K. Brown, E.M. Tompkins, I.N.H. White, Mass Spectrometry Reviews, 25 (2006) 127-145.

[28] M. Larsson, Mass Spectrometry Reviews, 27 (2008) 398-427.

[29] J. Barker, R.C. Garner, Rapid communications in mass spectrometry : RCM, 13 (1999) 285-293.

[30] T.J. Ognibene, J.S. Vogel, Synthesis and Applications of Isotopically Labelled Compounds, Proceedings of the International Symposium, 8th, Boston, MA, United States, June 1-5, 2003, (2004) 293-295.

[31] M. Gaskell, R. Jukes, D.J.L. Jones, E.A. Martin, P.B. Farmer, Chemical Research in Toxicology, 15 (2002) 10881095.

[32] J.S. Vogel, Nuclear Instruments \& Methods in Physics Research, Section B: Beam Interactions with Materials and Atoms, 172 (2000) 884-891.

[33] N.D. Priest, Journal of environmental monitoring : JEM, 6 (2004) 375-403.

[34] R. Peteranderl, C. Lechene, Journal of the American Society for Mass Spectrometry, 15 (2004) 478-485.

[35] G.K. Chuah, S. Jaenicke, T.H. Xu, Microporous and Mesoporous Materials, 37 (2000) 345-353.

[36] H.K. Farag, F. Endres, Journal of Materials Chemistry, 18 (2008) 442-449.

[37] M.M.a.D.A.A.-S. Barbooti, Thermochimica Acta, 98 (1986) 119-126.

[38] R.A. Yokel, J.M. Melograna, Biological Trace Element Research, 5 (1983) 225-237.

[39] R.D. Brauer, J.D. Robertson, P. Sharma, R.A. Yokel, Nuclear Instruments \& Methods in Physics Research, Section B: Beam Interactions with Materials and Atoms, 152 (1999) 129-134.

[40] G.B. T.J. Ognibene, J.S. Vogel, G.F. Peaslee, S. Murov, Anal. Chem., 75 (2003) 2192-2196.

[41] M.A. van Drunen, R. Finsy, H.G. Merkus, B. Scarlett, G.M. van Rosmalen, Journal of Crystal Growth, 134 (1993) 196-202.

[42] B.W. Wang, Peng; Yokel, Robert A.; Grulke, Eric A., Applied Surface Science, 258 (2012) 5232-5241.

[43] D. Krewski, R.A. Yokel, E. Nieboer, D. Borchelt, J. Cohen, J. Harry, S. Kacew, J. Lindsay, A.M. Mahfouz, V. Rondeau, Journal of Toxicology and Environmental Health, Part B: Critical Reviews, 10, Suppl 1 (2007) 1-269. [44] J. Sabol, P.-s. Weng, Introduction to Radiation Protection Dosimetry, World Scientific, 1995.

[45] R.L. Mehta, Ryan A.; Fitch, Hannah M.; Ali, Nawab; Soulsby, Michael; Chowdhury, Parimal, AlP Conference Proceedings, 1099 (2009) 259-264. 
398 Figure 1.

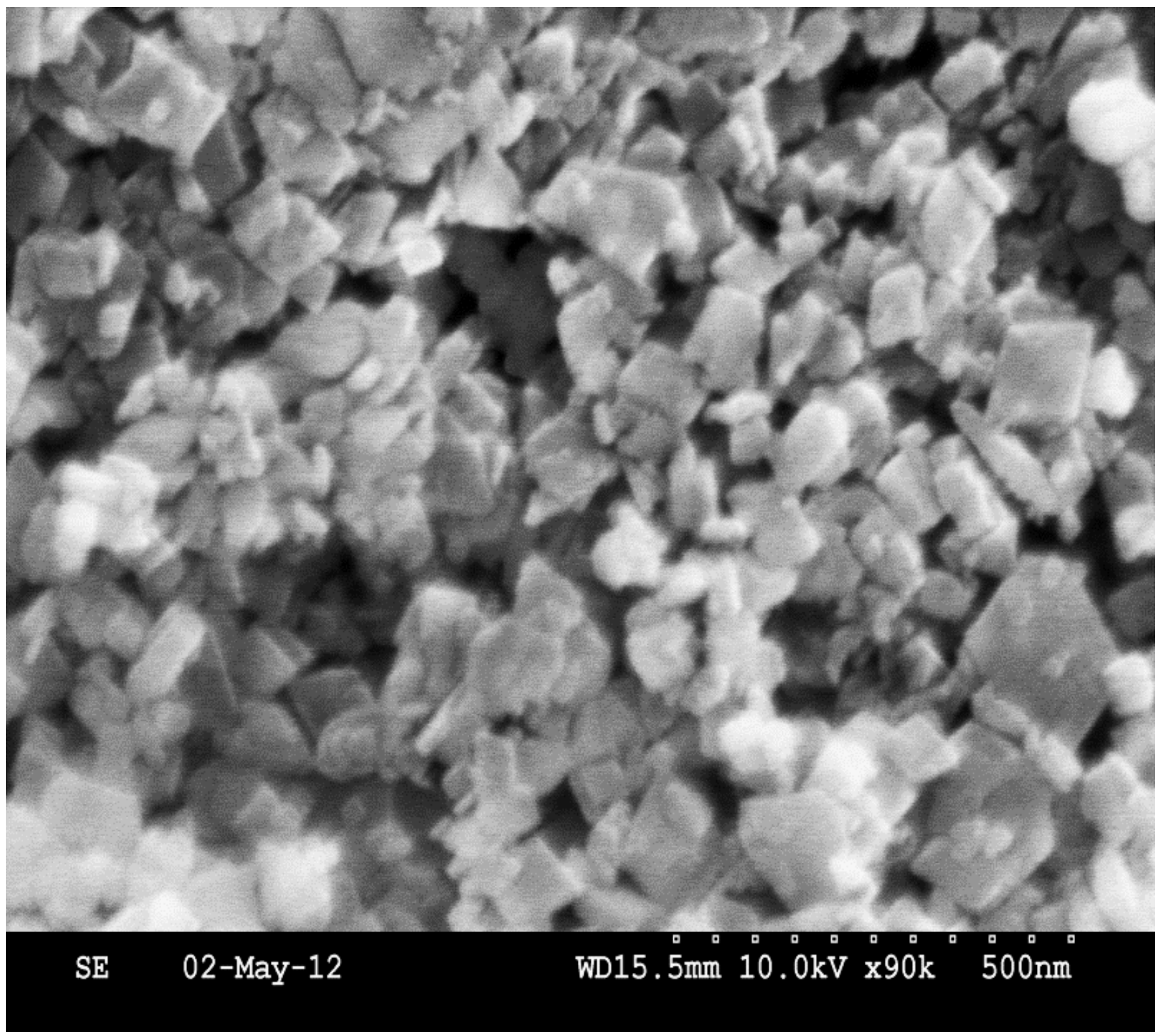


AMS detection of CENPs

$400 \quad$ Figure 2.

401

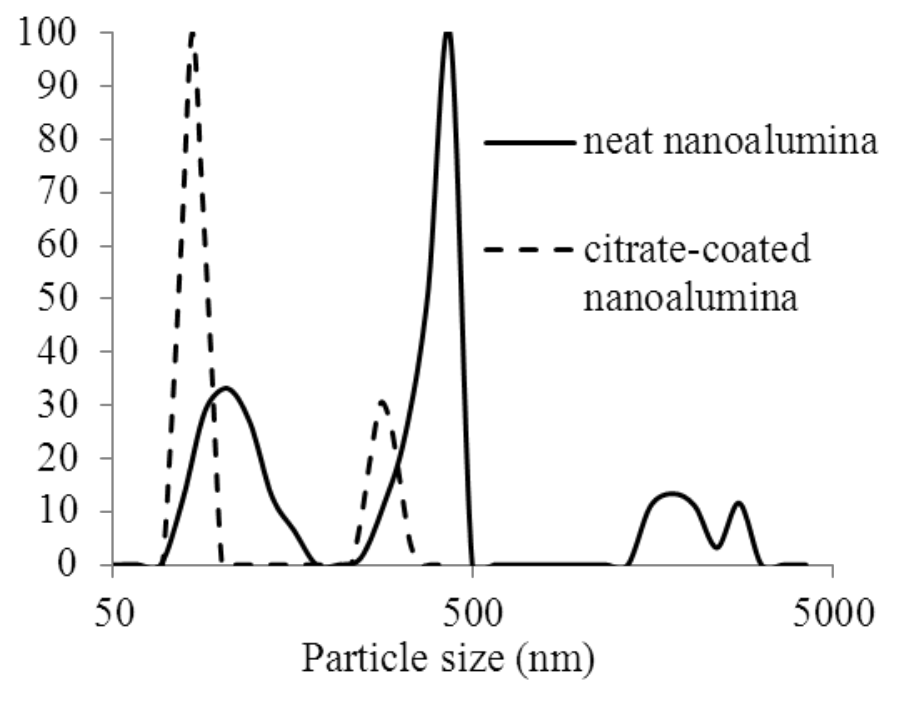

402

403

404 
AMS detection of CENPs

405 Figure 3.

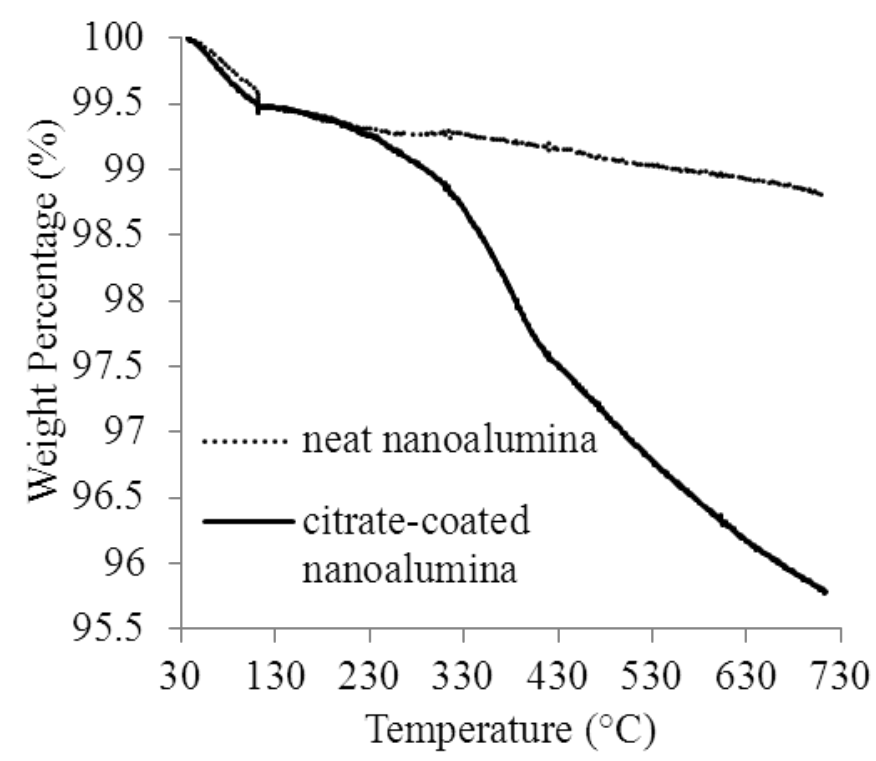

